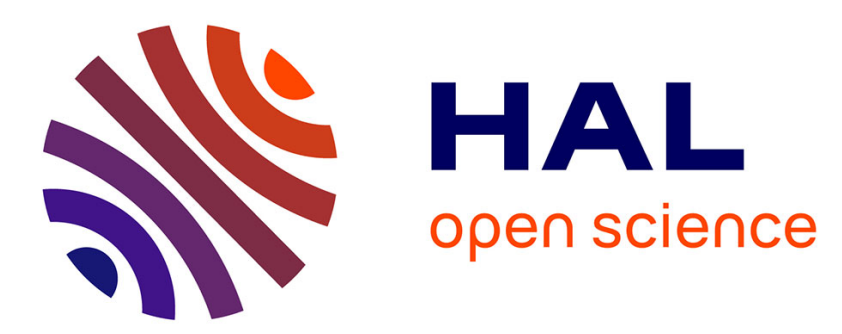

\title{
Age Determination and Lifespan of Marine Animal Species
}

Baptiste Le Bourg, Eric Le Bourg

\section{To cite this version:}

Baptiste Le Bourg, Eric Le Bourg. Age Determination and Lifespan of Marine Animal Species. Encyclopedia of Biomedical Gerontology. Elsevier. vol. 1, Academic Press, pp. 26-36., Elsevier, 2020, 9780128160756 . hal-02146485

\section{HAL Id: hal-02146485 https://hal.science/hal-02146485}

Submitted on 6 May 2020

HAL is a multi-disciplinary open access archive for the deposit and dissemination of scientific research documents, whether they are published or not. The documents may come from teaching and research institutions in France or abroad, or from public or private research centers.
L'archive ouverte pluridisciplinaire HAL, est destinée au dépôt et à la diffusion de documents scientifiques de niveau recherche, publiés ou non, émanant des établissements d'enseignement et de recherche français ou étrangers, des laboratoires publics ou privés. 


\title{
Age determination and lifespan of marine animal species
}

\author{
Baptiste Le Bourg, University of Liège, Belgium \\ Eric Le Bourg, CNRS and University of Toulouse, France
}

\section{Glossary}

Ectotherms: species whose internal temperature is dependent on the ambient temperature.

Endotherms: species whose internal temperature is fixed and regulated by the organism.

Fish: paraphyletic group of fin and gill-bearing aquatic vertebrates. The term is used for convenience and refers usually to the teleosts taxa, but some authors may also include other taxa (e.g. elasmobranchs).

Iteroparity: a reproductive strategy with several reproductive events during life, these events possibly occurring in successive years.

Life-history strategies: strategies selected by natural selection during evolution allowing species to develop, live, and propagate (e.g. species with a short lifespan and many offspring, like mice, vs long-lived species with a few offspring, like elephants).

Life-history traits: traits moulding life-history strategies (e.g. body size, age at maturity, duration of development, number of offspring, lifespan).

Marine species: aquatic species living in seas and oceans, as opposed to freshwater species living in rivers, ponds, lakes and so on.

Record lifespan: longest duration of life of individuals observed in a species. In most marine species, this age can reflect the age at capture and not the maximal lifespan, i.e. the lifespan of the last survivors.

\section{Key-words}

Age determination — growth bands — life-history strategies — lifespan — marine species — predation — sclerochronology — stable isotopes — temperature —

\section{Abstract}

Determining the lifespan of marine animals is not easy because they live underwater, in the wild, and not in the laboratory. Various indirect methods have been used to overcome this issue. This article describes these methods and tries to explain why some non-mammalian marine species can live so long, when compared to mammals, terrestrial or not. 


\section{Further reading}

Green BS, Mapstone BD, Carlos G, Begg G, (2009) Tropical fish otoliths: information for assessment, management and ecology. Dordrecht, Springer.

Panfili J, de Pontual H, Troadec H, Wright PJ (2002) Manual of fish sclerochronology. Ifremer-1RD coedition. https://archimer.ifremer.fr/doc/00017/12801/

Stearns SC (1992) The evolution of life histories. Oxford University Press.

\section{Relevant websites}

Fishbase: a global database of fish species, www.fishbase.org

\section{Acknowledgments}

Many thanks are due to Emmanuelle Cam, University of Brest, France and to Michel Marengo, University of Liège, Belgium, for their helpful comments on a previous version of this article.

\section{Introduction}

Lifespan of species does not evolve independently of other life-history traits such as fecundity, gestation time, parental care, but also body size, predatory pressure and so on. In terrestrial mammals, there is a continuum with, on one end, short-lived species (e.g. mice) with a small body size maturing quickly after a short gestation time and giving birth at short intervals to many offspring. On the other end of the continuum, there are large species (e.g. humans) with a long lifespan, a long gestation time and parental care, and giving birth to a few offspring during successive years [1]. The predatory pressure is linked to body size, mice being at a higher risk than, say, elephants. For the time being, it seems that the longest-lived terrestrial mammal is Homo sapiens with a 122 years recorded lifespan [2].

Marine animals include mammals, crustaceans, so-called fish (i.e. non-tetrapod craniates with gills and fins), molluscs, urchins, sea stars, sea turtles, and so on (marine birds are not within the scope of this article). When one compares the lifespan of marine animals to that of the longestlived terrestrial mammal, modesty is in order, because many species outlive it, not by decades, but by centuries. These long lifespans often intrigue people, like the roses in D'Alembert's Dream [3] saying that "in the memory of a rose no one had ever seen a gardener die".

How to explain the disparate lifespans of marine and other aquatic animals? Short life spans are not an issue, because they can be linked to ecological conditions prohibiting long lives. For 
instance, Notobranchius furzeri fish live in African ponds that dry every year. When it comes to happen, fish die and desiccation-resistant eggs survive in diapause in the mud, waiting for months for better times, i.e. for the rainy season. Because of such conditions that shaped life-history traits, $N$. furzeri live for less than 3 months in the laboratory [4]. A more extreme example is the coral reef fish Eviota sigillata whose adults are seemingly subjected to a high extrinsic mortality and live only for four weeks (larval stage: three weeks, [5]). Thus, while explaining short lifespans is not always an issue, the challenge could be to explain record lifespans of some marine animals.

As for other species, the lifespan depends on other life-history traits but, contrary to mammals, it can also depend on environmental conditions such as temperature, because most marine animals are ectotherms. Another difference with mammals is that fish can grow for many years, with a lower growth rate at older ages, but some species do not grow during their entire life [6]. The fecundity of fish also increases with age [7], which is opposite to mammals.

Table 1 lists recorded or inferred record lifespans, from shortest to longest lifespans, of various long-lived marine animals. However, determining lifespans of marine species is not easy because they live underwater in the wild, and it can be needed to rely on indirect methods (see below), because capturing and re-capturing animals living underwater is difficult. It is thus not surprising that it has been stated that a given species can live for, say, one century, even if there are no robust data to support this conclusion. For instance, it is commonly said that green sea turtles Chelonia mydas can live for 80 years, but not a single article has been published in support of this statement: these claims are not reported in Table 1. In the absence of a direct lifespan record, reported lifespans in Table 1 should be only considered as estimates, whose precision is dependent on the method used for estimation. 


\begin{tabular}{|c|c|c|c|}
\hline Species & Record lifespan (years) & Measuring method & Reference \\
\hline $\begin{array}{l}\text { North Atlantic right } \\
\text { whale Eubalaena } \\
\text { glacialis }\end{array}$ & $\geq 65$ & Sighting & [8] \\
\hline $\begin{array}{l}\text { European lobster } \\
\text { Homarus gamarrus }\end{array}$ & $72 \pm 9$ & $\begin{array}{l}\text { Age pigment } \\
\text { accumulation }\end{array}$ & [9] \\
\hline $\begin{array}{l}\text { Antarctic sea star } \\
\text { Odontaster validus }\end{array}$ & $>100$ & Growth rates & {$[10]$} \\
\hline $\begin{array}{l}\text { Orange roughy } \\
\text { Hoplostethus } \\
\text { atlanticus }\end{array}$ & $149 \pm 12(\mathrm{SD})$ & Radiometric analysis & {$[11]$} \\
\hline $\begin{array}{l}\text { Red sea urchin } \\
\text { Strongylocentrotus } \\
\text { franciscanus }\end{array}$ & $>200$ & Radiocarbon analysis & [12] \\
\hline $\begin{array}{l}\text { Tube worm } \\
\text { Lamellibrachia sp. }\end{array}$ & $170-250$ & $\begin{array}{l}\text { Staining of growing } \\
\text { tube worms and } \\
\text { growth rates }\end{array}$ & [13] \\
\hline $\begin{array}{l}\text { Bowhead whale } \\
\text { Balaena mysticetus }\end{array}$ & $211 \pm 35(\mathrm{SEM})$ & $\begin{array}{l}\text { Aspartic acid } \\
\text { racemisation in the eye } \\
\text { lens }\end{array}$ & [14] \\
\hline $\begin{array}{l}\text { Greenland shark } \\
\text { Somniosus } \\
\text { microcephalus }\end{array}$ & $\begin{array}{l}392 \pm 120(95.4 \% \\
\text { probability range })\end{array}$ & $\begin{array}{l}\text { Radiocarbon analysis } \\
\text { and growth rates }\end{array}$ & [15] \\
\hline $\begin{array}{l}\text { Bivalve clam Arctica } \\
\text { islandica }\end{array}$ & $>507$ & $\begin{array}{l}\text { Growth bands count } \\
\text { on shells }\end{array}$ & [16] \\
\hline $\begin{array}{l}\text { deep-sea sponge } \\
\text { Monorhaphis chuni }\end{array}$ & $11,000 \pm 3,000$ & Stable isotopes & [17] \\
\hline
\end{tabular}

Table 1. Some record lifespans, from shortest to longest, of some marine animals. Shortlived species are not reported. These records should not be considered as definitive, as they can reflect the age at capture and not the real lifespan. Abbreviations: SD: standard-deviation, SEM: standard-error of the mean.

\section{Measuring lifespans in marine organisms}

Most studies estimating the age of marine animals are done for fisheries stock management purpose. Indeed, poor age estimation (usually underestimation) may result in wrong estimation of growth and natural mortality rates, leading to risk of overexploitation of populations and their eventual collapse [18]. Consequently, it is critical to use accurate methods to estimate the age of marine animals.

Table 1 shows that various methods are used to determine age and lifespan. In the laboratory, 
recording birth and death date allows knowing lifespans of model species, e.g. flies or mice, which is not possible in most of the cases for marine animals not kept in the laboratory. Therefore, it is needed to implement other, indirect, methods to determine the age or lifespan of samples. The methodologies used to estimate age or lifespan of marine animals are more or less taxa or tissuespecific. For example, measurement of lead 210 and radium 226 ratio and quantification of lipofuscin are limited to teleost otoliths and crustacean brains respectively. By contrast, growth band counts and growth models are used in various taxa.

Most of the ageing methods are part of the discipline of sclerochronology, i.e. the study of physical and chemical variations in hard tissues in animals.

\section{Growth bands count}

Growth bands count is one of the most commonly used ageing method for marine animals. Alternation of growth bands, formed regularly from diurnal to annual time scales, can be observed on various hard tissues in various animal taxa. In some of these tissues, annual growth bands may appear as an alternation of opaque and translucent bands of different widths. Opaque bands appear as dark when observed with transmitted light but as bright when observed with reflected light or naked eye. They are wide and highlight a period of fast growth [19,20]. By contrast, translucent bands appear as bright when observed with transmitted light but as dark when observed with reflected light or naked eye. They are narrow and highlight a period of slow growth [19,20]. Opaque and translucent bands are also frequently associated with summer and winter temperatures respectively [19,20,21,22], although variations of this pattern may appear in some cases $[22,23,24]$. As a result, direct estimation of age is possible by counting alternations of growth bands.

Various tissues may be studied in order to estimate the age of marine animals with growth band counts (Fig. 1). For teleosts, age was previously estimated by counting annuli on scales but this method underestimates the age of old individuals [25,26]. From now on, age is usually estimated by counting growth increments in otoliths (Fig. 1a). Otoliths are present in various vertebrate taxa, but have been mainly studied in teleosts (e.g. [21,27,28]). Otoliths are calcified structures in the inner ears of teleosts and play a role in equilibration. They continue to grow as teleosts age [29,30] and are not resorbed even under conditions of high stress [31,32]. As a result, otoliths are considered as one of the best tools to estimate age of teleosts [30]. Analysis of sectioned otoliths appears to produce the highest and most accurate estimation of age by improving the readability of growth bands [26]. Statoliths (Fig. 1b) are a structure similar to otoliths present in various invertebrate taxa, and annual or daily growth increments in these structures can be used to 
estimate the age of box jellyfish [33,34], gastropods [35,36,37] and cephalopods [38,39,4 0]. In elasmobranchs (sharks and rays), growth bands are usually counted on sectioned vertebrae (e.g. [41,42,43], Fig. 1c). In squaliforme sharks, because annual growth bands are poorly visible on the vertebrae $[44,45,46]$, dorsal spines are used to estimate age, either by counting growth bands on the enameled surface $[45,46]$ or in the sectioned spine $[44,45]$. In holocephalans (chimaeras), a relative taxon of elasmobranchs, dorsal spines have no enameled surface and thus sectioned dorsal spines are used to estimate age [47]. In bivalves, age is estimated by counting annual growth increments in internal shells (Fig. 1d), which are less affected by environmental disturbances than external shells [23]. Other hard tissues displaying growth rings and being used or having the potential to be used for age estimation include jaws in errand polychaete $[48,49]$, cephalopod beaks [40,50], fin spines in billfish (Istiophoridae and Xiphiidae; [51,52] and teeth from odontocete whales [53].

However, using growth bands has several limitations and validation is still needed [18]. In old individuals, the increasing narrowness of growth bands at the edge of the studied structure $[21,54,55,56]$ reduces their visibility, leading to underestimation of age $[39,54,57]$. The increasing narrowness of growth bands is the result of a reduction of somatic growth rates with age. Overestimation of age may also occur when counting growth bands [58,59,60] as non-annual growth bands may appear [56,60,61]. It may be due to environmental factors that may alter the pattern of growth bands such as salinity [62] and food availability [55,62]. For example, slow growth translucent bands were previously known to be formed only during winter in internal shells of hard clams Mercenaria mercenaria in Rhode Island [63] but reduction of phytoplankton availability in summer led to the formation of slow growth translucent bands also in summer, meaning that a pattern of four bands instead of two became yearly for this species in this region. Furthermore, the compression of growth bands in older individuals reduces the visibility of the fall opaque band at the edge of the shell [55]. The pattern of growth bands may also not be yearly in hard tissues of some taxa $[58,62,64,65]$ making them invalid for age estimation. Moulting has also hampered direct estimation of crustacean age. As a result, the possibilities to directly estimate age of crustaceans using growth bands has begun to be investigated only recently in gastric mill and eyestalks (Fig. 1e) with contrasting results [66,67,68,69].

\section{Analysing chemistry of hard tissues}

Calcified structures also incorporate environmental elements during their formations but are usually metabolically inert once formed. As a result, compounds present in growth bands are 
preserved over time and variations of chemical composition occur from the core to the edge of the chemical structures [24]. These variations may be a tool for estimating age of marine animals but are mainly used to validate age estimation obtained by band counting [18] as these methods are more expensive than growth band counting.

Stable isotope ratios of oxygen $\left({ }^{18} \mathrm{O}:{ }^{16} \mathrm{O}\right.$, denoted $\left.\delta^{18} \mathrm{O}\right)$ in calcified structures are negatively linked to seawater temperature [70,71]. Consequently, cyclical variations of $\delta^{18} \mathrm{O}$ occur in calcified structures along seasons, with maximum $\delta^{18} \mathrm{O}$ during winter and minimum $\delta^{18} \mathrm{O}$ during summer. Thus, the number of $\delta^{18} \mathrm{O}$ cycles from the core to the edge of calcified structures may indicate the age of the organism. This method has been used either for age determination [72,73] or for validation of other methods $[37,60]$.

Another well-known methodology is bomb radiocarbon. Atmospheric nuclear testings in the late $1950 \mathrm{~s}$ led to an sharp increase of ${ }^{14} \mathrm{C}$ levels in the atmosphere and in the marine dissolved organic carbon. Indeed, the levels of ${ }^{14} \mathrm{C}$ in the environment are also integrated in the successive growth layers of calcified tissues of growing individuals [54,74,75,76], and in particular, in the core of the calcified tissues, i.e. the birth mark. The integration of environmental ${ }^{14} \mathrm{C}$ levels in organisms resulted in the appearance of a temporal profile of ${ }^{14} \mathrm{C}$ levels in environment and species that reflects the pre and post-bomb testing ${ }^{14} \mathrm{C}$ levels in the environment [76,77,78,79] (Fig. 2). As a result, ${ }^{14} \mathrm{C}$ levels in the core of calcified tissues reflect ${ }^{14} \mathrm{C}$ levels in the environment at the birth of individuals and thus can be used to estimate the age of animals [80,81] or, more frequently, to validate $[53,78,79,82,83]$ or adjust $[54,75]$ the year of birth determined with sclerochronology by comparing ${ }^{14} \mathrm{C}$ levels in studied organisms with a reference chronology of known-age animals (Fig. 2). The main drawbacks for this technique are that it is dependent on a time-specific event and that there are regional variations of ${ }^{14} \mathrm{C}$ levels and trends $[84,85]$.

The radiometric method consists in comparing the abundance of a radioactive isotope with its daughter product [86]. For ageing marine animals, the use of this method is limited to teleost otoliths as an assumption to this methodology is that the carbonate acts as a closed system. The most commonly used pair of radioactive isotopes are radium $226\left({ }^{226} \mathrm{Ra}\right)$ and lead $210\left({ }^{210} \mathrm{~Pb}\right)$. Radium is a naturally occurring radioactive element. Its isotopes are highly soluble in water in comparison of their parent and daughter radio-isotopes and efficiently absorbed by tissues as a proxy of calcium. As a result, radium is integrated in calcified tissues. In particular, teleost otoliths integrate ${ }^{226} \mathrm{Ra}$ and discriminate against its daughter radio-isotope ${ }^{210} \mathrm{~Pb}$. Consequently, the subsequent decay of ${ }^{226} \mathrm{Ra}$ into ${ }^{210} \mathrm{~Pb}$, which is itself retained by the otoliths, occurs at predictable rates according to the half-life of the two isotopes. As a result, the ratio of ${ }^{210} \mathrm{~Pb}$ over ${ }^{226} \mathrm{Ra}$ 
$\left({ }^{210} \mathrm{~Pb} /{ }^{226} \mathrm{Ra}\right)$ increases consistently and thus can be used as an independent chronometer to estimate the otolith's, and thus the teleost's, age. It is possible to determine ${ }^{210} \mathrm{~Pb} /{ }^{226} \mathrm{Ra}$ in both the whole otolith or the core of the otolith. However, analysing ${ }^{210} \mathrm{~Pb} /{ }^{226} \mathrm{Ra}$ in the whole otolith requires to take into account the growth of the otolith [11]. Indeed, as the otolith grows, it continuously integrates radium that subsequently decays, leading to variation of ${ }^{210} \mathrm{~Pb} /{ }^{226} \mathrm{Ra}$ from the core to the edge of the otolith. By contrast, ${ }^{210} \mathrm{~Pb} /{ }^{226} \mathrm{Ra}$ in the core provides more accurate ages [86] and improvement of technology made it possible to work on small amounts of samples. ${ }^{210} \mathrm{~Pb} /{ }^{226} \mathrm{Ra}$ has been used either to assess the age of teleosts of age up to 100 years or as a validation tool for growth zones count (e.g. $[11,56,76,87,88]$. Another pair of isotopes that can used to estimate teleost age is thorium 228 $\left({ }^{228} \mathrm{Th}\right)$ and radium $228\left({ }^{228} \mathrm{Ra}\right)$. However, as the age limit with this dating method is 10 years [86], this method is more suited to estimate the age of short-lived teleosts. However, it has only been used once [89] since its first documentary reference [86].

\section{Other methods outside of the sclerochronology discipline}

Lipofuscin are fluorescent aggregates made of oxidised proteins and lipids that are no more degraded by cell metabolism and thus continuously accumulate within lysosomal residual bodies. Consequently, in areas of the brain where neurons persist throughout life, lipofuscin is accumulated with age in various taxa, notably crustaceans [90]. The correlation between lipofuscin content and age of crustaceans $[9,91]$ led lipofuscin quantification to be a common tool to estimate the age of crustaceans [68]. Lipofuscin quantification can be done by using successive histological sections of the brain where lipofuscin is quantified as an area fraction (e.g. [92,93]) or percent volume fraction (e.g. [9,91]). Lipofuscin content can also be determined using spectrophotometry and is expressed as a concentration relative to protein content (e.g. $\mu$ g.mg ${ }^{-1}$ protein, e.g. [94,95]). Age determination can thus be done by using the relationship between lipofuscin content and age in individuals of known age (e.g. $[9,91]$ ), or by separating age groups derived from lipofuscin content frequency histograms (e.g. [92,93,95]).

Limited knowledge on growth rates of an organism may allow a preliminary estimation of lifespan. However, these lifespans are highly likely to be inaccurate or imprecise. For example, the antarctic sea star Odontaster validus was estimated to live between 50 and 100 years but these ages were estimated assuming that the growth rate of $O$. validus with age is linear [10]. However, animals grow until a maximum size and then continue to live. Actually, growth of animals usually follows the von Bertalanffy's [96] growth model, where growth rates decrease with age as length is approaching an asymptote. Knowledge on variations of growth rates during life and several given parameters (e.g. size at birth) allow to generate growth models. These growth models then help to 
estimate the age of animals according to their size, and longevity is estimated according to the age estimated for the largest organism (e.g. $[12,13,15])$.

\section{Attempting to explain long lifespans of some species}

Some long-lived marine animals can live strikingly longer than terrestrial ones. While the maximal recorded lifespan of humans is 122 years, clams can live at least for 5 centuries and sharks for ca 400 years and, at a first sight, such lifespans are astounding. Yet, some mechanisms explaining lifespan of terrestrial species may be applied to marine animals too.

\section{Longevity and life-history strategies}

Longevity is an integral part of life history strategies. Species reproducing in a single season, as mice do [97], are not expected to live long simply because a long life is not necessary to make the species thrive. These species are well able to quickly take advantage of plentiful food to reproduce heavily: they are called opportunistic species [98]. This life-history strategy is also present in the marine environment. Opportunistic species include animals such as small pelagic teleosts (i.e. anchovies and sardines), with a small size, a fast maturation, a rather short lifespan (from 1.5 to 15 years, [58,99]), and strong abundance fluctuations over time. One can thus understand why the stock of these species (e.g. the numerous anchovies) can recover if overfished [100]. However, some of these opportunistic species still have a lifespan (e.g. 13 years in Pacific sardines and 15 years in herrings) that may be considered as long in, say, dogs, and a challenge is to explain why "short-lived" fish can live so long. Another example of opportunistic species are planktonic cladocerans which have population maxima during periods of favourable conditions but are practically absent from the water column for the rest of the year. Indeed, their life cycle is characterised by fast maturation and a period of asexual reproduction followed by a period of sexual reproduction, resulting in the seasonal abundance fluctuations for this group [101,102].

By contrast, species unable to quickly reproduce and thrive even if resources are plentiful are called equilibrium species [98], such as for instance humans that can only have one offspring every two years at a maximum and need parental care for ca 15 years. This pattern is not only observed in terrestrial species but also in marine ones. Marine species with low fecundity reproduce repeatedly during life, and the offspring need time to reach maturity. This is the case for whales or sharks. For instance, short-finned pilot whales have their first calf at 8-10 years of age, after a ca 16 months gestation, sucking lasting for ca 5 years and up to 15 years for the last calf [103]. Such a life- 
history strategy requires living long for whales being able to survive and the species to thrive.

However, a main difference between the so-called fish and mammals is that, even if marine biologists make use of the term "parental investment" in fish [104], this investment is rudimentary when compared to parental care in mammals. In the best of the cases, parents will simply protect larvae from predators, like the male lingcod Ophiodion elongatus does [105]. As a result, while elasmobranchs are still considered as equilibrium species because of low fecundity, large eggs and important parental investment (e.g. gestation), long-living teleosts may instead be considered as "periodic strategists" [99]. Periodic strategists are "slow-growing, long-lived demersal species (with) a lower degree of variability in abundance" and the authors stressed that lifespans greater than 20 years ensure "a relatively long reproductive cycle, which minimises the risk that periods of unfavourable environmental conditions will result in the loss of a stock". However, teleosts, like most other marine taxa, actually display a great fecundity by releasing large numbers of eggs in the water column. It is a little bit surprising that long-lived animals can display a great fecundity, by contrast to terrestrial mammals, but one should not forget that one million of eggs of an oviparous marine organism does not mean one million of new adults, because of a high predatory pressure on eggs and juveniles for instance. Fish often grow throughout life and their fecundity increases with age [7], but the increased number of eggs produced by older fish could result in only a few more adult fish than at younger ages. Yet, laying as many eggs as possible may be the only available lifehistory strategy when eggs are simply dispersed in water, and thus offered to predators. Therefore, the increased fecundity with age could explain why many fish live long: without a long lifespan, these fish could not reproduce and these species would be extinct.

\section{Temperature and metabolism of ectotherm species}

Fish and other marine animals, except mammals, are ectotherms and, as for any ectotherm species, their lifespan is expected to be longer at lower temperatures [106]. However, experimentally testing this hypothesis can only be done with very short-lived species for obvious reasons. For instance, mean lifespans of the freshwater fish Cynolebias belotti are 14 months at 25 ${ }^{\circ} \mathrm{C}$ and 19 months at $20^{\circ} \mathrm{C}$ : transfer at 8 months of age from $20{ }^{\circ} \mathrm{C}$ to $15^{\circ} \mathrm{C}$ increases lifespan to 23 months, while the reverse change has nearly no effect (15 months; [107]).

Because temperature is lower in deep sea than near the surface, it has been hypothesised that deeper-dwelling fish live long, but as deep sea also means higher pressure, lower light, oxygen, and food levels than near the surface (references in [108]), it is rather difficult to tease apart these factors. In any case, the evidence showing that deep-sea fish live longer is fragile: in a review on deep-dwelling fish, Cailliet et al. [108] concluded that metabolic rate was lower with increasing 
depth, and that because of a lower oxygen pressure, oxidative stress could be lower, all of this possibly explaining long lives but, as stressed by the authors "our findings are at best correlative". Another review on bivalves showed that depth only explains $4 \%$ or the variance of lifespan (Fig. S4 in [109], and see also [110]), bivalves living longer at higher depths, but there is a caveat in the fact that most of depths were in the 0-100 $\mathrm{m}$ range.

Nevertheless, it remains that a low temperature could explain partly why fish and other ectotherm marine species can live so long. For instance, sampled Salmo trutta trouts are older at higher latitudes in Norway where water temperature decreases [111]. Bivalves of various species have been shown to live longer at higher latitudes, and thus in increasingly cold waters, even if this is not always observed (Fig. S2 in [109]). This results not only from temperature decrease per se, because predation is more important in the tropics and metabolism could be lower at higher latitudes because of a reduced food supply during winter [109]. If food supply is lower at high latitudes, starvation could occur. It has been argued that species unable to emigrate in the event of starvation have to wait at the same place for better times and thus that food restriction can make them living longer (e.g. nematodes, mice), while larger and less predated species (e.g. elephants, humans) do not need to live longer because they can emigrate to discover new food sources [112]. Because bivalves cannot emigrate, one could make the hypothesis that food restriction would increase their lifespan: such a hypothesis could be tested with short-lived bivalves. By contrast, whales or sharks could try to discover new food sources and thus food restriction could have no effect on lifespan: anyway, it is simply impossible to test this hypothesis by recording lifespan of food-restricted whales or sharks.

Therefore, it seems possible to explain why ectotherm marine species can live long. Their metabolism is highly dependent on their environment, not only regarding temperature, but also food supply, and it is not surprising that a long lifespan, for instance in some bivalve species, has been selected. Because bivalves can hardly move away, populations could become extinct and possibly the whole species, too, if they were unable to sustain a low food supply: like spiders on their web, Arctica islandica clams have to wait for food coming to them and, as spiders [113], living longer can be a strategy to wait for better times. Combined with a low temperature under the surface, and thus a longer life with lower temperature as in other ectotherms, this could make they can live long. However, this would not be observed if life would be ended at an early age because of a severe predatory pressure.

A low predatory pressure...except from fishery

Overfishing is an issue, particularly for slow-growing long-lived species. Fisheries predate 
preferably large subjects, while marine predators usually prefer prey smaller than their own size, because gape limitation prohibits ingesting too large individuals (see e.g. [114]). Indeed, as large subjects need an extended time to grow, catching them means catching the most prolific ones, which can make soon a species becoming endangered, at risk not to recover even after years or decades $[115,116]$, and these consequences are similar to those of hunting adult African elephants, even if does not result in extinction [117]. Predating large subjects could select for animals investing their resources in reproduction at an earlier age at the expense of their size [118].

Therefore, the main predator of marine species is the fisherman and not the marine predators. It has been estimated that "among nonhuman predators across all oceans, $50 \%$ of exploitation rates were less than $1 \%$ of annual adult biomass. In contrast, fisheries exploited more than $10 \%$ of adult biomass in $62 \%$ of cases. Overall, the median fishing rate $(0.14)$ was 14.1 times the take $(0.01)$ by marine predators" [119]. Therefore, in the absence of fishing, it can be assumed that the predatory pressure is low and sustainable. Oceans are immense, and for many species they are a threedimensional world allowing more escape than for mice in sight of a cat, for instance. This may explain why even the highly predated sardines during the sardine run in South Africa [120] can sustain such an annual toll in a few days, and this every year from ancient times.

For slow-growing species, a long lifespan is mandatory; thus, if protected from predators, because they can escape or hide in the ground like clams do, individuals of these species can indeed live long. The clam A. islandica is buried in sands and is hardly visible, waiting for carbon particles and, as stressed by Morton [121], "the lifestyle of $A$. islandica is characterised by slow, deliberate, near undetectable, movements possibly to avoid detection". Therefore, if the predatory pressure is low, there is no selective pressure for a reduced lifespan combined with a higher fecundity at younger ages (see [122]) and longer lifespan can evolve, as in opossums living on an island free from predators for millenaries [123]. This could be particularly the case for the clam A. islandica that can live for 5 centuries [16].

However, it may happen that a mere accident has dire consequences and kill most animals. For instance, A. islandica clams were subjected to a mass extinction in Iceland after a storm. Innumerable clams were "swept from their natural sandy habitat at depth of more than $9 \mathrm{~m}$, up onto the hard bottom in shallower water (7-9 m)" and thus, "lying exposed, unable to escape, they were easy prey for fish as wolffish... and invertebrate predators" [124]. One year after the storm, only empty shells and no living clam were seen on the ground.

\section{Marine ectotherms and mammals}


Therefore, taking into account a lower metabolism at lower temperatures in ectotherms, a low predation rate, a fecundity often increasing with age, and iteroparity, it seems possible to (partly?) explain why marine species can live so long. However, it remains that marine ectotherms can live much longer than marine mammals. Table 1 shows that Greenland shark Somniosus microcephalus can live for 4 centuries while the whales Eubalaena glacialis live only for several decades and Balaena mysticetus up to 200 years. Thus, in the best case, mammals live for only half the lifespan of large Greenland sharks: it could be linked to the fact that sharks are ectotherms and not endotherms like whales.

The 211-year lifespan of the bowhead whale B. mysticetus is however not exceptional, given that this whale is the largest living mammal and that larger mammals usually live longer [1]. Indeed, bowhead whales live only twice as long as humans, a species with a small body size when compared to the up to 100 tonnes whales. However, it is a caveat that the 122-years lifespan of the recordwoman Jeanne Calment has been observed among several billions of people, while sharply less bowhead whales can be observed, with a lower chance to observe exceptional individuals. The other massive blue and fin whales (Balaenoptera musculus and Balaenoptera physalus, indicated respectively just below the bowhead whales point on Fig. 3) do not display an extraordinary lifespan. Therefore, the long lifespan of marine mammals is far from being exceptional when compared to other mammals, even if they are long-lived, and does not depart from the general trend linking the log of body mass and the log of maximal lifespan in mammals (Fig. 3): explaining the lifespan of marine mammals is not an issue but explaining why only rather large marine mammals exist is surely an issue. The marine otter Lontra felina, which weighs ca $4 \mathrm{~kg}$ and whose lifespan is unknown (and thus not shown on Fig. 3), is probably the smallest marine mammal [125].

By contrast, lifespans of marine ectotherms can be impressive and are not so easy to explain: more studies are necessary to ascertain and explain the variation of lifespan among marine species. 
a)

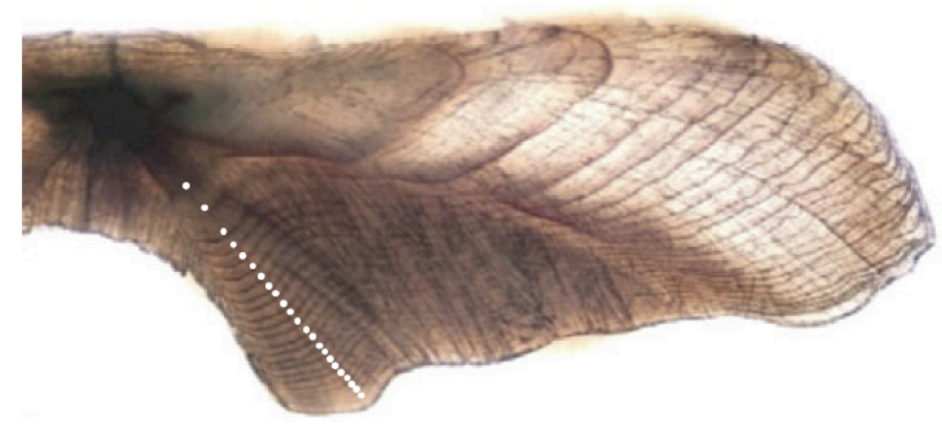

c)

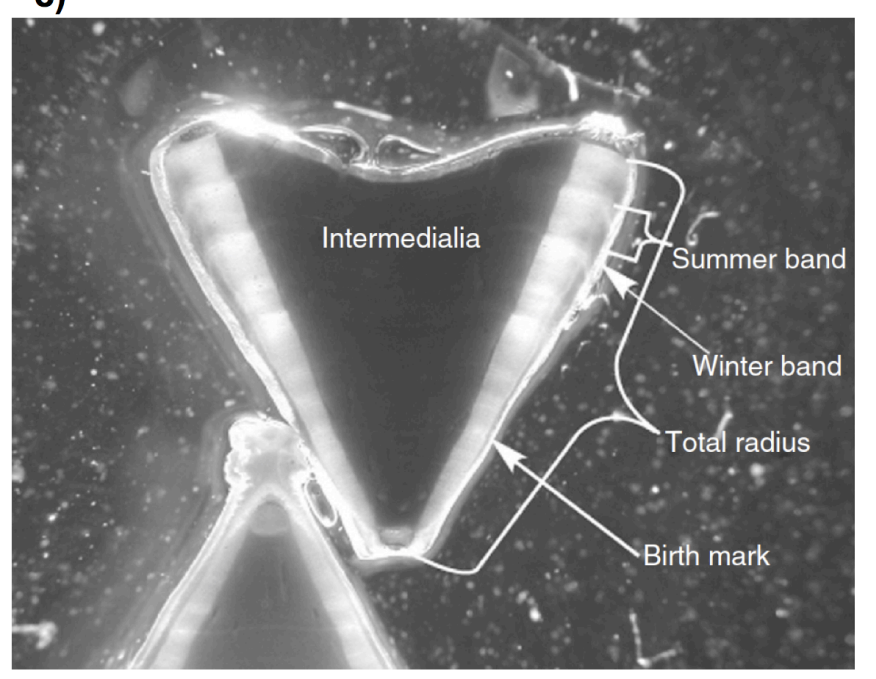

d) b)

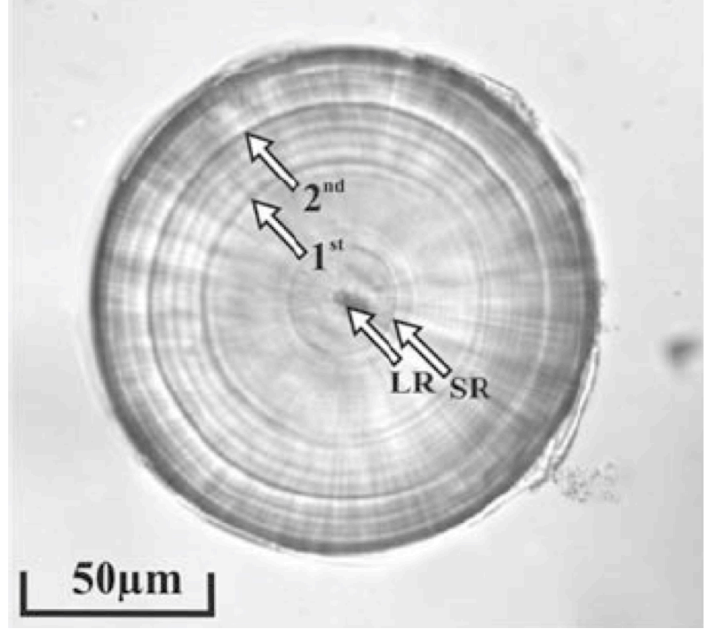

e)

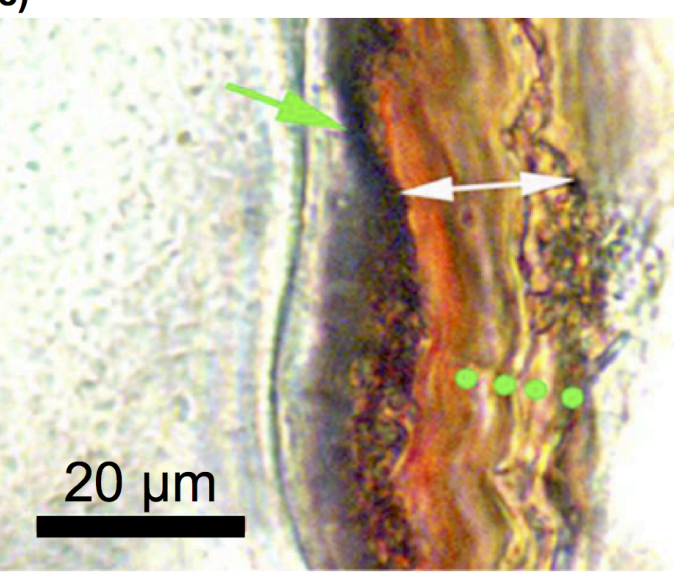

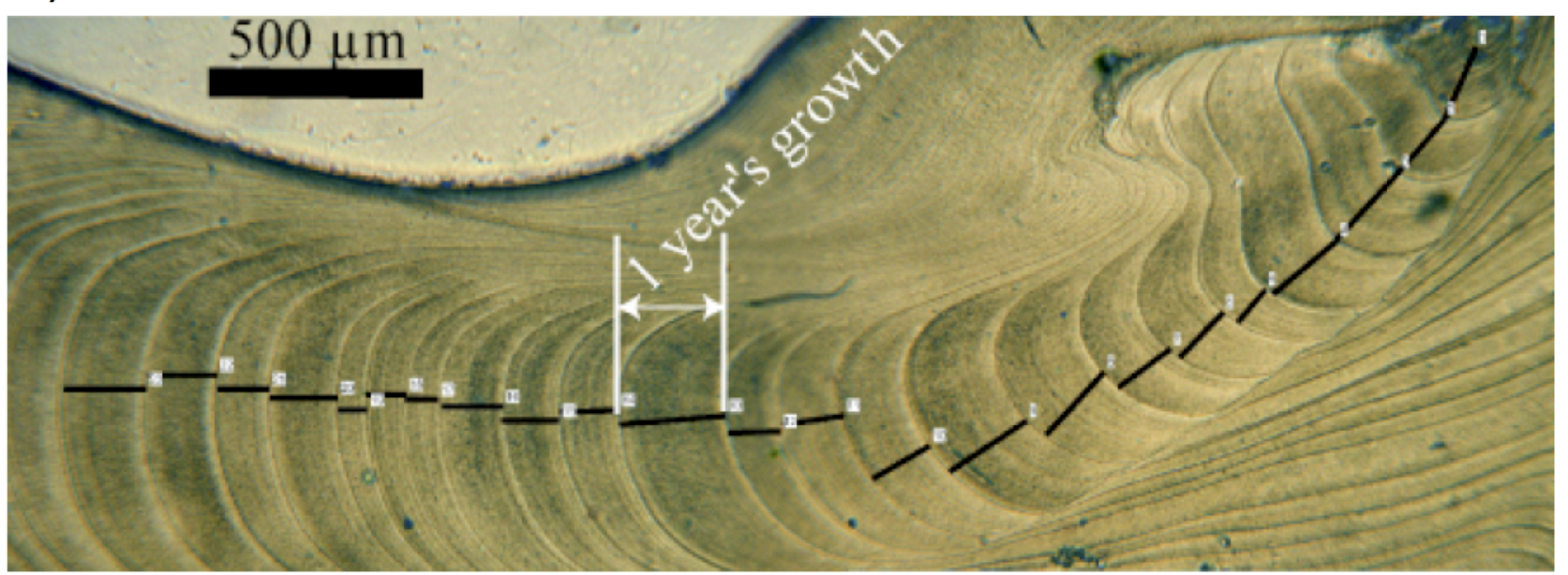

Figure 1. Examples of tissues displaying growth bands and being used to estimate the age of marine animals. a) sectioned otolith from a 23 year-old teleost (Dentex dentex). Annual growth bands are indicated by white dots. Picture from [126]. b) Statolith from a gastropod (Polinices pulchellus) with larval ring (LR), settlement ring (SR), and two years growth rings $\left(1^{\text {st }}\right.$ and $\left.2^{\text {nd }}\right)$. Picture from [127]. c) Sagittally sectioned vertebrae from a 4 year-old shark (Spyrna lewini). 
Picture from [128]. d) Sectioned shell from a bivalve (Arctica islandica) with each black bar showing one year of growth. Picture from [129]. e) Sectioned eyestalk of a 4 year-old crustacean (Euphausia superba). Annual growth bands are indicated by green dots. Green and white arrows respectively indicate the epicuticle and endocuticle layers. Picture modified from [69]. Reprinted with permission. 


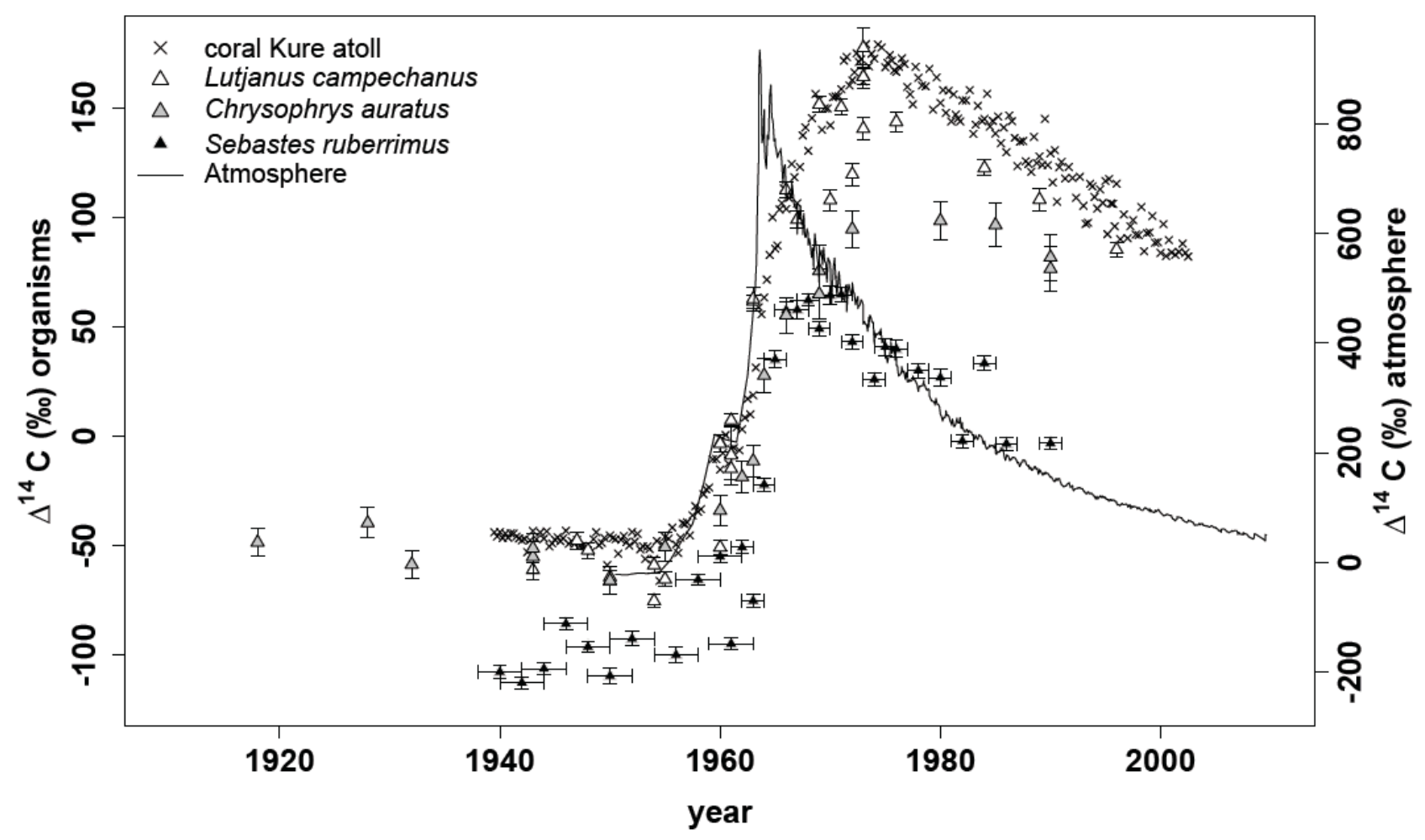

Figure 2. Temporal evolution of ${ }^{14} \mathrm{C}$ levels $\left(\Delta^{14} \mathrm{C}\right)$ recorded in coral layers from Kure Atoll (Northwestern Hawaiian Islands, [76]), in otolith cores from Lutjanus campechanus from the northern Gulf of Mexico [78], Chrysophrys auratus from New Zealand [77] and Sebastes ruberrimus from southeast Alaska [79] and in the atmosphere of the northern hemisphere (zone 2, [130]). 


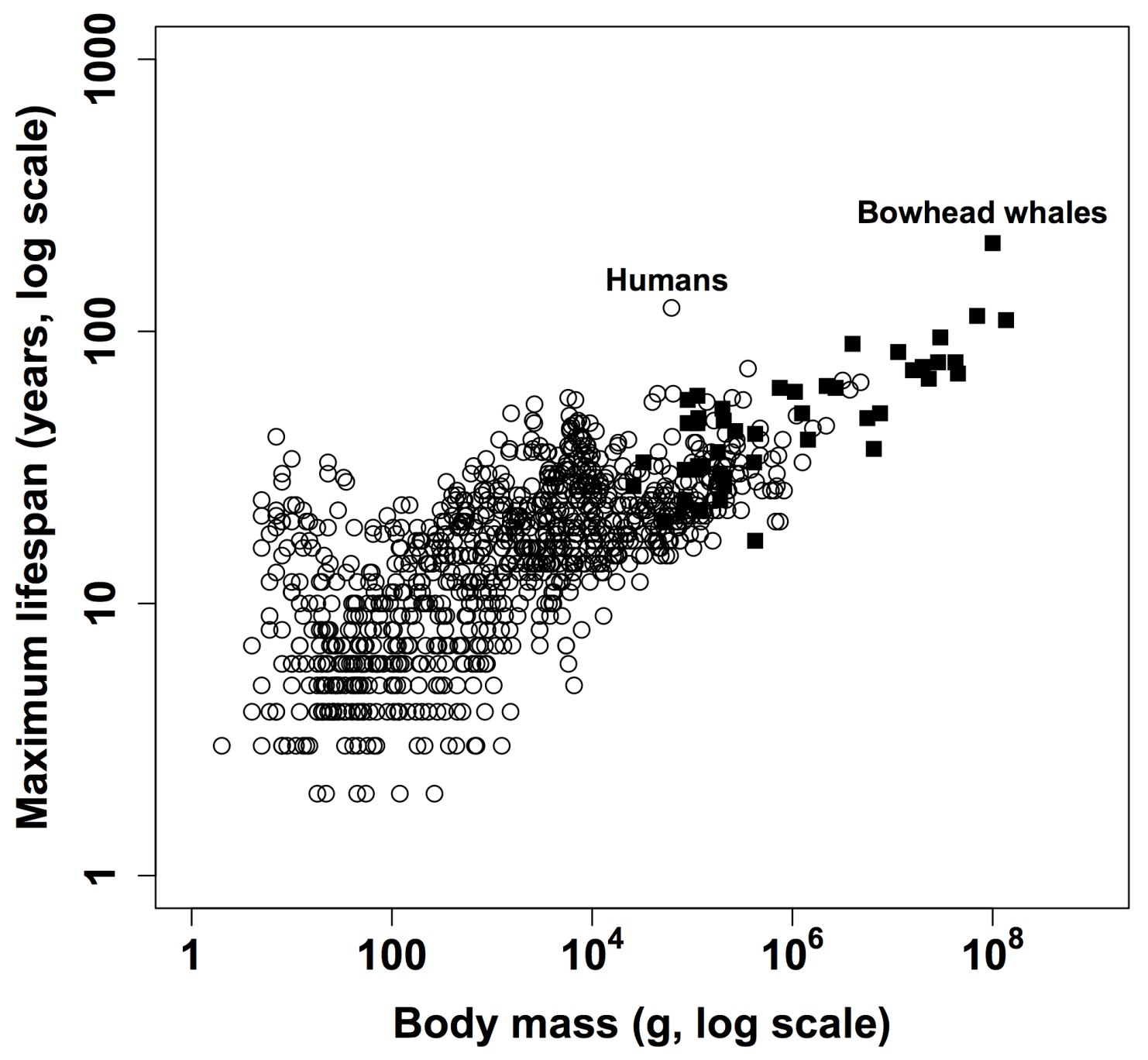

Figure 3. Relationship between body mass and maximal lifespan in mammal species (log scales). Drawn from the database AnAge (http:/genomics.senescence.info/species/, [131]. Each point is for a species and marine mammals are shown with black squares. 
[1] S.C. Stearns, The influence of size and phylogeny on patterns of covariation among lifehistory traits in the mammals, Oikos 41 (1983) 173-187.

[2] B. Jeune, J.M. Robine, R. Young, et al., Jeanne Calment and her successors. Biographical notes on the longest living humans, in: H. Maier, J. Gampe, B. Jeune, J.M. Robine, J.W. Vaupel (Eds.), Supercentenarians, Springer, Berlin Heidelberg, 2010, pp. 285-323.

[3] D. Diderot, Le rêve d'Alembert. In CEuvres complètes de Diderot. Assézat Tourneux, Garnier Frères, tome 2, edition of 1875, Paris, 1769.

[4] A. Cellerino, Life extension in the short-lived fish Notobranchius furzeri, in: C. Sell, A. Lorenzini, H.M. Brown-Borg (Eds.), Life-span extension. Single-cell organisms to man, Berlin Heidelberg: Humana Press, 2009, pp. 157-171.

[5] M. Depczynski, D.R. Bellwood, Shortest recorded vertebrate lifespan found in a coral reef fish, Current Biology 15 (2005) R288-R289.

[6] A.D. Woodhead, Feral fishes, in: F.A. Lints (Ed.), Non-mammalian models for research on aging, Karger, Basel, 1985, pp. 22-50.

[7] D. Reznick, C. Ghalambor, L. Nunney, The evolution of senescence in fish. Mechanisms of Ageing and Development 123 (2002) 773-789.

[8] P.K. Hamilton, A.R. Knowlton, M.K. Marx, S.D. Kraus, Age structure and longevity in North Atlantic right whales Eubalaena glacialis and their relation to reproduction, Marine Ecology Progress Series 171 (1998) 285-292.

[9] M.R.J. Sheehy, R.C.A. Bannister, J.F. Wickins, P.M.G. Shelton, New perspectives on the growth and longevity of the European lobster (Homarus gammarus), Canadian Journal of Fisheries and Aquatic Sciences 56 (1999) 1904-1915.

[10] J.S. Pearse, Antarctic sea star. Australian Natural History 16 (1969) 234-238.

[11] G.E. Fenton, S.A. Short, D.A. Ritz, Age determination of orange roughy, Hoplostethus atlanticus (Pisces: Trachichthyidae) using ${ }^{210} \mathrm{~Pb}:{ }^{226} \mathrm{Ra}$ disequilibria, Marine Biology 109 (1991) 197-202.

[12] T.A. Ebert, J.R. Southon, Red sea urchins (Strongylocentrotus franciscanus) can live over 100 years: confirmation with A-bomb 14carbon, Fishery Bulletin 101 (2003) 915-922.

[13] D.C. Bergquist, F.M. Williams, C.R. Fisher, Longevity record for deep-sea invertebrate, Nature 403 (2000) 499-500.

[14] J.C. George, J. Bada, J. Zeh, et al., Age and growth estimates of bowhead whales (Balaena mysticetus) via aspartic acid racemization, Journal of Canadian Zoology 77 (1999) 571-580.

[15] J. Nielsen, R.B. Hedeholm, J. Heinemeier, et al., Eye lens radiocarbon reveals centuries of longevity in the Greenland shark (Somniosus microcephalus), Science 353 (2016) 702-704.

[16] P.G. Butler, A.D. Wanamaker Jr, J.D. Scourse, C.A. Richardson, D.J. Reynolds, Variability of 
marine climate on the North Icelandic Shelf in a 1357-year proxy archive based on growth increments in the bivalve Arctica islandica, Paleogeography Paleoclimatology Paleoecology 373 (2013) 141-151.

[17] K.P. Jochum, X. Wang, T.W. Vennemann, B. Sinha, W.E.G. Müller, Siliceous deep-sea sponge Monorhaphis chuni: a potential paleoclimate archive in ancient animals, Chemical Geology 300-301 (2012) 143-151.

[18] S.E. Campana, Accuracy, precision and quality control in age determination, including a review of the use and abuse of age validation methods, Journal of Fish Biology 59 (2001) $197-242$.

[19] A.J. Fowler, Age in years from otoliths of adult tropical fish, in: B.S. Green, B.D. Mapstone, G. Carlos, G. Begg (Eds.), Tropical fish otoliths: information for assessment, management and ecology, Springer, Heidelberg, 2009, pp. 55-92.

[20] N. Aldanondo, U. Cotano, P. Álvarez, A. Uriarte, Validation of the first annual increment deposition in the otoliths of European anchovy in the Bay of Biscay based on otolith microstructure analysis, Marine and Freshwater Research 67 (2016) 943-950.

[21] M. La Mesa, S. Colella, G. Giannetti, E. Arneri, Age and growth of brown meagre Sciaena umbra (Sciaenidae) in the Adriatic Sea, Aquatic Living Ressources 21 (2008) 153-161.

[22] C.B. Wakefield, I.C. Potter, N.G. Hall, R.C.J. Lenanton, S.A. Hesp, Timing of growth zone formations in otoliths of the snapper, Chrysophrys auratus, in subtropical and temperate waters differ and growth follows a parabolic relationship with latitude, ICES Journal of Marine Science 74 (2017) 180-192.

[23] D.S. Jones, Sclerochronology: reading the record of the molluscan shell, American Scientist 71 (1983) 384-391.

[24] D.S. Jones, I.R. Quitmyer, Marking time with bivalve shells: oxygen isotopes and season of annual increment formation, PALAIOS 11 (1996) 340-346.

[25] R.J. Beamish, G.A. McFarlane, The forgotten requirement for age validation in fisheries biology, Transactions of the American Fisheries Society 112 (1983) 735-743.

[26] M. Baudoin, M. Marengo, A. Pere, et al., Comparison of otolith and scale readings for age and growth estimation of common dentex Dentex dentex, Journal of Fish Biology 88 (2016) 760-766.

[27] E. Kadison, E.K. D'alessandro, G.O. Davis, P.B. Hood, Age, growth, and reproductive patterns of the great barracuda, Sphyraena barracuda, from the Florida Keys, Bulletin of Marine Science 86 (2010) 773-784.

[28] P.N. Yershov, C. Marshal, A.V. Ereskovsky, A.E. Vishnyakov, New data on the longevity of coastal cod Gadus morhua Linnaeus, 1758 in the White Sea, Journal of Applied Ichthyology 
32 (2016) 350-352.

[29] A.J. Fowler, P.J. Doherty, Validation of annual growth increments in the otoliths of two species of damselfish from the southern Great Barrier Reef, Australian Journal of Marine and Freshwater Research 43 (1992) 1057-1068.

[30] S.E. Campana, S.R. Thorrold, Otoliths, increments, and elements: keys to a comprehensive understanding of fish populations?, Canadian Journal of Fisheries and Aquatic Sciences 58 (2001) 30-38.

[31] S.E. Campana, Feeding periodicity and the production of daily growth increments in otoliths of steelhead trout (Salmo gairdneri) and starry flounder (Platichthys stellatus). Canadian Journal of Zoology 61 (1983) 1591-1597.

[32] S.E. Campana, Calcium deposition and otolith check formation during periods of stress in coho salmon, Oncorhynchus kisutch, Comparative Biochemistry and Physiology Part A: Physiology 75 (1983) 215-220.

[33] S. Ueno, C. Imai, A. Mitsutani, Fine growth rings found in statolith of a cubomedusa Carybdea rastoni, Journal of Plankton Research 17 (1995) 1381-1384.

[34] M. Gordon, C. Hatcher, J. Seymour, Growth and age determination of the tropical Australian cubozoan Chiropsalmus sp, Hydrobiologia 530/531 (2004) 339-345.

[35] C.M. Barroso, M. Nunes, C.A. Richardson, M.H. Moreira, The gastropod statolith: a tool for determining the age of Nassarius reticulatus, Marine Biology 146 (2005) 1139-1144.

[36] C.A. Richardson, P.R. Kingsley-Smith, R. Seed, E. Chatzinikolaou, Age and growth of the naticid gastropod Polinices pulchellus (Gastropoda: Naticidae) based on length frequency analysis, Marine Biology 148 (2005) 319-326.

[37] P.R. Hollyman, M.J. Leng, S.R.N. Chenery, V.V. Laptikhovsky, C.A. Richardson, Statoliths of the whelk Buccinum undatum: a novel age determination tool, Marine Ecology Progress Series 598 (2018) 261-272.

[38] G.D. Jackson, J.W. Fortsythe, R.F. Hixon, R.T. Hanlon, Age, growth, and maturation of Lolliguncula brevis (Cephalopoda: Loliginidae) in the northwestern Gulf of Mexico with a comparison of length-frequency versus statolith age analysis, Canadian Journal of Fisheries and Aquatic Sciences 54 (1997) 2907-2919.

[39] V. Bettencourt, A. Guerra, Age studies based on daily growth increments in statoliths and growth lamellae in cuttlebone of culture Sepia officinalis, Marine Biology 139 (2001) 327334.

[40] B.L. Liu, X.J. Chen, Y. Chen, G.Y. Hu, Determination of squid age using upper beak rostrum sections: technique improvement and comparison with the statolith, Marine Biology 162 (2015) 1685-1693. 
[41] G.B. Skomal, L.J. Natanson, Age and growth of the blue shark (Prionace glauca) in the North Atlantic Ocean, Fishery Bulletin 101 (2003) 627-639.

[42] A.N. Piercy, J.K. Carlson, J.A. Sulikowski, G.H. Burgess, Age and growth of the scalloped hammerhead shark, Sphyrna lewini, in the north-west Atlantic Ocean and Gulf of Mexico, Marine and Freshwater Research 58 (2007) 34-40.

[43] C. Porcu, A. Bellodi, R. Cannas, et al., Life-history traits of the commercial blonde ray, Raja brachyura, from the central-western Mediterranean Sea, Mediterranean Marine Science 16 (2015) 90-102.

[44] M.W. Clarke, P.L. Connoly, J.J. Bracken, Age estimation of the exploited deepwater shark Centrophorus squamosus from the continental slopes of the Rockall Trough and Porcupine Bank, Journal of Fish Biology 60 (2002) 501-514.

[45] J.M. Braccini, B.M. Gillanders, T.I. Walker, J. Tovar-Avila, Comparison of deterministic growth models fitted to length-at-age data of the piked spurdog (Squalus megalops) in southeastern Australia, Marine and Freshwater Research 58 (2007) 24-33.

[46] C.F. Cotton, R.D. Grubbs, T.S. Day-Engel, P.D. Lynch, J.A. Musick, Age, growth and reproduction of a common deep-water shark, shortspine spurdog (Squalus cf. mitsukurii), from Hawaiian waters, Marine and Freshwater Research 62 (2011) 811-822.

[47] E. Calis, E.H. Jackson, C.P. Nolan, F. Jeal, Preliminary age and growth estimates of the rabbitfish, Chimaera monstrosa, with implications for future resource management, Journal of the Northwest Atlantic Fishery Science 35 (2005) 15-26.

[48] T.A. Britayev, V.V. Belov, Age determination of Polynoidae polychaetes based on growth lines on the jaws, Hydrobiological Journal 30 (1994) 53-60.

[49] M. Plyuscheva, D. Martin, T. Britayev, Population ecology of two simpatric polychaetes, Lepidonotus squamatus and Harmothoe imbricata (Polychaeta, Polynoidae), in the White Sea, Invertebrate Zoology 1 (2004) 65-73.

[50] C. Perales-Raya, A. Bartolomé, M.T. García-Santamaría, P. Pascual-Alayón, E. Almansa, Age estimation obtained from analysis of octopus (Octopus vulgaris Cuvier,1797) beaks: improvements and comparisons. Fisheries Research 106 (2010) 171-176.

[51] R.K. Kopf, K. Drew, R.L. Humphreys Jr, Age estimation of billfishes (Kajikia spp.) using fin spine cross-sections: the need for an international code of practice, Aquatic Living Resources 23 (2010) 13-23.

[52] T. Shimose, K. Yokawa, K. Tachihara, Age determination and growth estimation from otolith micro-increments and fin spine sections of blue marlin (Makaira nigricans) in the western North Pacific, Marine and Freshwater Research 66 (2015) 1116-1127.

[53] R.E.A. Stewart, S.E. Campana, C.M. Jones, B.E. Stewart, Bomb radiocarbon dating calibrates 
beluga (Delphinapterus leucas) age estimates, Canadian Journal of Zoology 84 (2006) 18401852.

[54] M.P. Francis, S.E. Campana, C.M. Jones, Age under-estimation in New Zealand porbeagle sharks (Lamna nasus): is there an upper limit to ages that can be determined from shark vertebrae?, Marine and Freshwater Research 58 (2007) 10-23.

[55] K.M. Henry, R.M. Cerrato, The annual macroscopic growth pattern of the northern quahog [=hard clam, Mercenaria mercenaria (L.)], in Narragansett Bay, Rhode Island, Journal of Shellfish Research 26 (2007) 985-993.

[56] C.M. Brooks, A.H. Andrews, J.R. Ashford JR, et al.,. Age estimation and lead-radium dating of Antarctic toothfish (Dissostichus mawsoni) in the Ross Sea, Polar Biology 34 (2011) 329338.

[57] A.V. Harry, Evidence for systemic age underestimation in shark and ray ageing studies, Fish and Fisheries 19 (2018) 185-200.

[58] T.M. Greely, J.V. Gartner Jr, J.J. Torres, Age and growth of Electrona antarctica (Pisces: Myctophidae), the dominant mesopelagic fish of the Southern Ocean, Marine Biology 133 (1999) 145-158.

[59] A.H. Andrews, Lead-radium dating of Pacific cod (Gadus macrocephalus) - validation of the young-fish scenario, Marine and Freshwater Research 67 (2016) 1982-1986.

[60] C.R. Kastelle, T.E. Hesler, J.L. McKay, et al., Age validation of Pacific cod (Gadus macrocephalus) using high-resolution stable oxygen isotope $\left(\delta^{18} \mathrm{O}\right)$ chronologies in otoliths, Fisheries Research 185 (2017) 43-53.

[61] A. Uriarte, I. Rico, B. Villamor, et al., Validation of age determination using otoliths of the European anchovy (Engraulis encrasicolus L.) in the Bay of Biscay. Marine and Freshwater Research 67 (2016) 951-966.

[62] C.A. Narvaez, L.E. Johnson, B. Sainte-Marie, Growth bands are an unreliable indicator of sea urchin age: Evidence from the laboratory and the literature, Limnology and Oceanography: Methods 14 (2016) 527-541.

[63] D.S. Jones, M.A. Arthur, D.J. Allard, Sclerochronological records of temperature and growth from shells of Mercenaria mercenaria from Narragansett Bay, Rhode Island, Marine Biology 102 (1989) 225-234.

[64] C.R. Fisher, I.A. Urcuyo, M.A. Simpkins, E. Nix, Life in the slow lane: growth and longevity of cold-seep vestimentiferans, Marine Ecology 18 (1997) 83-94.

[65] M.P. Russel, R.W. Meredith, Natural growth lines in echinoid ossicles are not reliable 
indicators of age: a test using Strongylocentrotus droebachiensis, Invertebrate Biology 119 (2000) 410-420.

[66] R. Kilada, B. Sainte-Marie, R. Rochette, N. Davis, C. Vanier, et al., Direct determination of age in shrimps, crabs, and lobsters, Canadian Journal of Fisheries and Aquatic Sciences 69 (2012) 1728-1733.

[67] M. Sheridan, I. O’Connor, A. Henderson, Investigating the effect of molting on gastric mill structure in Norway lobster (Nephrops norvegicus) and its potential as a direct ageing tool, Journal of Experimental Marine Biology and Ecology 484 (2016) 16-22.

[68] R. Kilada, J.G. Driscoll, Age determination in crustaceans: a review, Hydrobiologia 799 (2017) 21-36.

[69] R. Kilada, C.S. Reiss, S. Kawaguchi, R.A. King, T. Matsuda, et al., Validation of band counts in eyestalks for the determination of age of Antarctic krill, Euphausia superba, PLoS ONE 12 (2017) e0171773.

[70] S. Epstein, R. Buchsbaum, H. Lowenstam, H.C. Urey, Carbonate-water isotopic temperature scale, Bulletin of the Geological Society of America 62 (1951) 417-426.

[71] S. Epstein, R. Buchsbaum, H. Lowenstam, H.C. Urey, Revised carbonate-water isotopic temperature scale, Bulletin of the Geological Society of America 64 (1953) 1315-1326.

[72] L.J. Gurney, C. Mundy, M.C. Porteus, Determining age and growth of abalone using stable oxygen isotopes: a tool for fisheries management, Fisheries Research 72 (2005) 353-360.

[73] J.R. Naylor, B.M. Manighetti, H.L. Neil, S.W. Kim, Validated estimation of growth and age in the New Zealand abalone Haliotis iris using stable oxygen isotopes, Marine and Freshwater Research 58 (2007) 354-362.

[74] R.T. Leaf, A.H. Andrews, G.M. Cailliet GM, T.A. Brown, The feasibility of bomb radiocarbon analysis to support an age-at-length relationship for red abalone, Haliotis rufescens Swainson in Northern California, Journal of Shellfish Research 27 (2008) 11771182.

[75] L.L. Hamaday, L.J. Natanson, G.B. Skomal, S.R. Thorrold, Vertebral bomb radiocarbon suggests extreme longevity in white sharks, PLoS ONE 9 (2014) e84006.

[76] A.H. Andrews, D. Siciliano, D.C. Potts, E.E. DeMartini, S. Covarrubias, Bomb radiocarbon and the Hawaiian archipelago: coral, otoliths and seawater, Radiocarbon 58 (2016) 531-548.

[77] J.M. Kalish, Pre- and post-bomb radiocarbon in fish otoliths, Earth and Planetary Science Letters 114 (1993) 549-554.

[78] M.S. Baker MS, C.A. Wilson, Use of bomb radiocarbon to validate otolith section ages of red snapperLutjanus campechanus from the northern Gulf of Mexico. Limnology and Oceanography 46 (2001) 1819-1824. 
[79] L.A. Kerr, A.H. Andrews, B.R. Frantz, K.H. Coale, T.A. Brown, et al., Radiocarbon in otoliths of yelloweye rockfish (Sebastes ruberrimus): a reference time series for the coastal waters of southeast Alaska, Canadian Journal of Fisheries and Aquatic Sciences 61 (2004) 443-451.

[80] A.H. Andrews, E.J. Burton, L.A. Kerr, et al., Bomb radiocarbon and lead-radium disequilibria in otoliths of bocaccio rockfish (Sebastes paucispinis): a determination of age and longevity for a difficult-to-age fish, Marine and Freshwater Research 56 (2005) 517-528.

[81] E.B. Roark, T.P. Guilderson, S. Flood-Page, et al., Radiocarbon-based ages and growth rates of bamboo corals from the Gulf of Alaska. Geophysical Research Letters 32 (2005) L04606.

[82] S.E. Campana, Natanson LJ, Myklevoll S (2002) Bomb dating and age determination of large pelagic sharks. Canadian Journal of Fisheries and Aquatic Sciences 59: 450-455.

[83] J.D. Neilson, S.E. Campana, A validated description of age and growth of western Atlantic bluefin tuna (Thunnus thynnus), Canadian Journal of Fisheries and Aquatic Sciences 65 (2008) 1523-1527.

[84] A. Mahadevan, An analysis of bomb radiocarbon trends in the Pacific, Marine Chemistry 73 (2001) 273-290.

[85] J.D. Scource, A.D. Wanamaker Jr, C. Weidman, et al., The marine radiocarbon bomb pulse across the temperate North Atlantic: a compilation of $\Delta^{14} \mathrm{C}$ time histories from Arctica islandica growth increments, Radiocarbon 54 (2012) 165-186.

[86] J.N. Smith, R. Nelson, S.E. Campana, The use of Pb-210/Ra-226 and Th-228/Ra-228 disequilibria in the ageing of otoliths of marine fish, in: P.J. Kershaw, D.S. Woodhead (Eds.), Radionuclides in the study of marine processes, Elsevier Applied Science, New York, 1991 pp. 350-359.

[87] A.H. Andrews, J.R. Ashford, C.M. Brooks, et al., Lead/radium dating provides a framework for coordinating age estimation of Patagonian toothfish (Dissostichus eleginoides) between fishing areas, Marine and Freshwater Research 62 (2011) 781-789.

[88] A.H. Andrews, D.M. Tracey, M.R. Dunn, Lead-radium dating of orange roughy (Hoplostethus atlanticus): validation of a centenarian life span, Canadian Journal of Fisheries and Aquatic Sciences 66 (2009) 1130-1140.

[89] S.E. Campana, H.A. Oxenford, J.N. Smith, Radiochemical determination of longevity in flyingfish Hirundichthys affinis using Th-228/Ra-228, Marine Ecology Progress Series 100 (1993) 211-219.

[90] M.R.J. Sheehy, Widespread occurrence of fluorescent morphological lipofuscin in the crustacean brain. Journal of Crustacean Biology 10 (1990) 613-622.

[91] M.R.J. Sheehy, Potential of morphological lipofuscin age-pigment as an index of crustacean 
age. Marine Biology 107 (1990) 439-442.

[92] B.A. Bluhm, T. Brey, Age determination in the Antarctic shrimp Notocrangon antarcticus Crustacea: Decapoda), using the autofluorescent pigment lipofuscin, Marine Biology 138 (2001) 247-257.

[93] B.A. Bluhm, T. Brey, M. Klage, The autofluorescent age pigment lipofuscin: key to age, growth and productivity of the Antarctic amphipod Waldeckia obesa (Chevreux, 1905), Journal of Experimental Marine Biology and Ecology 258 (2001) 215-235.

[94] S.J. Ju, D.H. Secor, H.R. Harvey, Use of extractable lipofuscin for age determination of blue crab Callinectes sapidus, Marine Ecology Progress Series 185 (1999) 171-179.

[95] K.M. Bosley, B.R. Dumbaul, Use of extractable lipofuscin to estimate age structure of ghost shrimp populations in west coast estuaries of the USA, Marine Ecology Progress Series 428 (2011) 161-176.

[96] L. von Bertalanffy, Untersuchungen über die Gesetzlichkeit des Wachstums. I. Allgemeine Grundlagen der Theorie; mathematische und physiologische Gesetzlichkeiten des Wachstums bei Wassertieren, Wilhelm Roux' Archiv für Entwicklungsmechanik der Organismen 131 (1934) 613-652.

[97] J.P. Phelan, S.N. Austad, Natural selection, dietary restriction, and extended longevity. Growth Development and Aging 53 (1989) 4-5.

[98] L. Demetrius, Of mice and men. When it comes to studying ageing and the means to slow it down, mice are not just small humans, EMBO Reports 6 (2005) S39-S44.

[99] J.R. King, G.A. McFarlane, Marine fish life history strategies: applications to fishery management, Fisheries Management and Ecology 10 (2003) 249-264.

[100]P.B. Adams, Life history patterns in marine fishes and their consequences for fisheries management, Fishery Bulletin 78 (1980) 1-12.

[101]D. Atienza, E. Saiz, A. Skovgaard, I. Trepat, A. Calbe, Life history and population dynamics of the marine cladoceran Penilia avirostris (Branchiopoda: Cladocera) in the Catalan Sea (NW Mediterranean), Journal of Plankton Research 30 (2008) 345-357.

[102]L.K. Miyashita, S.A. Gaeta, R.M. Lopes, Life cycle and reproductive traits of marine podonids (Cladocera, Onychopoda) in a coastal subtropical area, Journal of Plankton Research 33 (2011) 779-792.

[103]H.J. Bernard, S.B. Reilly, The pilot whales, Globicephala sp., in: S. Ridgway, R. Harrison (Eds.), Handbook of Marine Mammals, Vol 6. Academic Press, Orlando, 1999, pp. 245-279.

[104]K.O. Winemiller, Patterns of variation in life history among South American fishes in seasonal environments, Oecologia 81 (1989) 225-241.

[105]V.M. O’Connell, Submersible observations on lingcod, Ophiodon elongatus, nesting below 
30 m off Sitka, Alaska, Marine Fisheries Review 55 (1993) 19-24.

[106]S.B. Munch, S. Salinas, Latitudinal variation in lifespan within species is explained by the metabolic theory of ecology, Proceedings of the National Academy of Sciences of the USA 106 (2009) 13860-13864.

[107]R.K. Liu, R.L. Walford, Mid-life temperature-transfer effects on life-span of annual fish, Journal of Gerontology 30 (1975) 129-131.

[108] G.M. Cailliet, A.H. Andrews, E.J. Burton, D.L. Watters, D.E. Kline, L.A. Ferry-Graham, Age determination and validation studies of marine fishes: do deep-dwellers live longer? Experimental Gerontology 36 (2001) 2001) 739-764.

[109]D.K. Moss, L.C. Ivany, E.J. Judd, et al., Lifespan, growth rate, and body size across latitude in marine Bivalvia, with implications for Phanerozoic evolution, Proceedings of the Royal Society B 283 (2016) 20161364.

[110]I. Montero-Serra, C. Linares, D.F. Doark, J.B. Ledoux, J. Garrabou. Strong linkages between depth, longevity and demographic stability across marine sessile species, Proceedings of the Royal Society B 285 (2018) 20172688.

[111]B. Jonsson, J.H. L'Abée-Lund, T.G. Heggberget, et al., Longevity, body size, and growth in anadromous brown trout (Salmo trutta), Canadian Journal of Fisheries and Aquatic Sciences 48 (1991) 1838-1845.

[112]E. Le Bourg, The somatotropic axis may not modulate ageing and longevity in humans, Biogerontology 14 (2016) 421-429.

[113]S.N. Austad, Life extension by dietary restriction in the bowl and doily spider, Frontinella pyramitela. Experimental Gerontology 24 (1989) 83-92.

[114]R.J. Schmitt, S.J. Holbrook, Gape-limitation, foraging tactics and prey size selectivity of two microcarnivorous species of fish. Oecologia 63 (1984) 6-12.

[115]J.A. Musick, Ecology and conservation of long-lived marine animals, American Fisheries Society Symposium 23 (1999) 1-10.

[116]L.A.K. Barnett, T.A. Branch, R.A. Ranasinghe, T.E. Essington, Old-growth fishes become scarce under fishing, Current Biology 27 (2017) 2843-2848.

[117]O. Le Pape, S. Bonhommeau, A.E. Nieblas, J.M. Fromentin, Overfishing causes frequent fish population collapses but rare extinctions, Proceedings of the National Academy of Sciences of the USA 114 (2017) E6274.

[118]U. Dieckmann, M. Heino, A. Rijnsdorp, The dawn of Darwinian fishery management, ICES Insight 9 (2009) 34-43.

[119]C.T. Darimont, C.H. Fox, H.M. Bryan, T.E. Reimchen, The unique ecology of human predators, Science 349 (2015) 858-860. 
[120]C.D. van der Lingen, J.C. Coetzee, L. Hutchings, Overview of the KwaZulu-Natal sardine run, African Journal of Marine Science 32 (2010) 271-277.

[121]B. Morton, The biology and functional morphology of Arctica islandica (Bivalvia: Arcticidae): A gerontophilic living fossil, Marine Biology Research 7 (2011) 540553.

[122]E. Le Bourg, Evolutionary theories of aging can explain why we age, in: L. Robert, T. Fulop (Eds.), Aging: facts and theories, Interdisciplinary Topics in Gerontology, Karger, Basel, 39 (2014) 8-23.

[123] S.N. Austad, Retarded senescence in an insular population of Virginia opossums (Didelphis virginiana), Journal of Zoology London 229 (1993) 695-708.

[124]G.G. Thórarindsóttir, K. Gunnarsson, E. Bogason, Mass mortality of ocean quahog, Arctica islandica, on hard substratum in Lonafjordur, north-eastern Iceland after a storm, Marine Biodiversity records 2 (2009) e55.

[125]J. Valqui, The marine otter Lontra felina (Molina, 1782): A review of its present status and implications for future conservation, Mammalian Biology 77 (2012) 75-83.

[126]M. Baudouin, M. Marengo, A. Pere, J.-M. Culioli, M.-C. Santoni, B. Marchand, E. D. H. Durieux, Comparison of otolith and scale readings for age and growth estimation of common dentex Dentex dentex, Journal of Fish Biology 88 (2016) 760-766.

[127]C.A. Richardson, P.R. Kingsley-Smith, R. Seed, E. Chatzinikolaou, Age and growth of the naticid gastropod Polinices pulchellus (Gastropoda: Naticidae) based on length frequency analysis and statolith growth rings, Marine Biology 148 (2005) 319-326.

[128]A.N. Piercy, J.K. Carlson, J.A. Sulikowski, G.H. Burgess, Age and growth of the scalloped hammerhead shark, Sphyrna lewini, in the north-west Atlantic Ocean and Gulf of Mexico. Marine and Freshwater Research, 58 (2007), 34-40.

[129]A.D. Wanamaker Jr, J. Heinemeier, J.D. Scourse, et al., Very long-lived mollusks confirm 17 th century ad tephra-based radiocarbon reservoir ages for north icelandic shelf waters. Radiocarbon 50 (2008) 399-412.

[130]Q. Hua, M. Barbetti, A.Z. Rakowski, Atmospheric radiocarbon for the period 1950-2010, Radiocarbon 55 (2013) 2059-2072.

[131]R. Tacutu R, T. Craig T, A. Budovsky, D. Wuttke, G. Lehmann, D. Taranukha, J. Costa4, V.E. Fraifeld, J.P. de Magalhaes, Human ageing genomic resources: integrated databases and tools for the biology and genetics of ageing, Nucleic Acids Research 41 (2013) D1027D1033. 